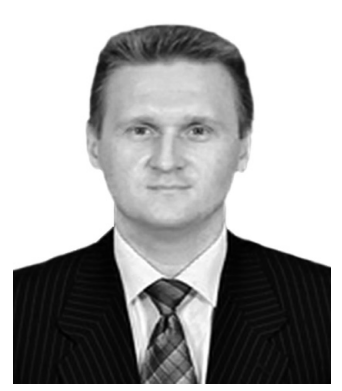

\title{
ПЕРСПЕКТИВИ ЗАЛУЧЕННЯ ГРОМАДЯН ДО ОХОРОНИ ГРОМАДСЬКОГО ПОРЯДКУ В УКРАЇ̈І
}

ЗАВАЛЬНИЙ Михайло Володимирович - доктор юридичних наук, старший науковий співробітник, доцент кафедри адміністративного права i процесу факультету №1 Харківського національного університету внутрішніх справ; директор Науково-дослідного інституту публічної політики і соціальних наук https://orcid.org/0000-0003-4191-061X DOI 10.32782/LAW.2020.3.6

\section{Постановка проблеми}

Правоохоронна діяльність е силу своєї багатоаспектності й особливостей виконуваних функцій та завдань припускає активні дії не лише спеціалізованих органів і служб, але й багатьох інших установ і організацій, що здійснюють різні державні й недержавні повноваження. Складно знайти державний орган або громадську організацію, які не зацікавлені в ефективній правоохоронній діяльності, що й не реалізують ії хоча 6 у деякій частині. Правоохоронна діяльність зачіпає законні інтереси кожної людини, має високу суспільну значимість і дуже впливає на формування правової держави. Незважаючи на активну роль цих органів, підрозділи Національної поліції України, інші державні суб’єкти правоохорони здійснюють активну співпрацю щодо забезпечення правопорядку в країні як з окремими громадянами, так і їхніми об'єднаннями. Вітчизняне законодавство прямо передбачає можливість участі громадян в охороні громадського порядку й забезпеченні безпеки в країні. Насамперед, мова йде про громадські формування з охорони громадського порядку та державного кордону. Громадяни України відповідно до Конституції України мають право створювати громадські об'єднання для участі в охороні громадського порядку і державного кордону, сприяння органам місцевого самоврядування, правоохоронним органам, Державній прикордонній службі України та органам виконавчої влади, а також посадовим особам у запобіганні та припиненні ад- міністративних правопорушень і злочинів, захисті життя та здоров'я громадян, інтересів суспільства і держави від протиправних посягань, а також у рятуванні людей i майна під час стихійного лиха та інших надзвичайних обставин [1].

\section{Стан дослідження}

Проблеми правового регулювання участі громадян в охороні громадського порядку неодноразово ставали предметом дослідження цілої плеяди вітчизняних адміністративістів: В. Б. Авер'янова, М. І. Ануфpiєва, Ю. П. Битяка, I. П. Голосніченка, Є. В. Додіна, А. Т. Комзюка, О. В. Кузьменко, О. М. Музичука, В. І. Олефіра, О. І. Остапенка, С. С. Юрка тощо.

Метою статті $є$ визначення перспектив існування та діяльності громадських формувань, діяльність яких спрямована на охорону громадського порядку та безпеки.

Виклад основного матеріалу

Необхідність залучення громадян до охорони громадського порядку та їхньої взаємодії з підрозділами Національної поліції України та іншими органами 3 правоохоронними функціями. Метою такої співпраці є протидія злочинним проявам та адміністративним правопорушенням. Однак, незважаючи на активне декларування необхідності широкого залучення громадян до охорони правопорядку, відсутня система діяльність як правотворців, так і органів вико- 
навчої влади в цьому напрямку. Незначний масштаб залучення громадськості до забезпечення правопорядку є побічним наслідком руйнування старої радянської системи, яка мала значний досвід 3 цього питання. Добровільні народні дружини та інші аналогічні структури мали масове поширення в країні. Наприкінці існування добровільні народні дружини налічували майже чотири мільйони залучених осіб. Підприємства та організації забезпечували існування значної кількості таких структур. За даними на 1990 рік в Українській РСР налічувалося понад 30 тисяч ДНД. За даними Департаменту персоналу, організації освітньої та наукової діяльності МВС України штатна чисельність Національної поліції України складає 149 тис. працівників. Таким чином, добровільні народні дружини мали дійсно широке поширення в нашій країні. Проблема зниження кількості осіб, які залучаються до охорони правопорядку, потребує додаткового дослідження. Насамперед, необхідно чітко визначити причини такого різкого зменшення активності населення, розробити концепцію підвищення їхньої ролі в охороні громадського порядку та взаємодії з правоохоронними органами.

Е засобах масової інформації поширеними $є$ публікації про те, що останніми роками значно підвищується активність громадян у забезпеченні безпеки в країні та усуненні внутрішніх та зовнішніх загроз. На превеликий жаль, мусимо констатувати, що в цьому випадку здійснюється певна підміна понять. Звісно, протягом 2014-2018 років було створено досить багато добровільних формувань правоохоронної спрямованості. Однак їхне створення й подальша діяльність відбувалась із значними порушеннями вимог законодавства. Так звані активісти нерідко привласнювали суто державні повноваження щодо застосування сили до пересічних громадян. Діяльність таких структур нерідко пов'язується з порушеннями прав і свобод громадян. Такий стан справ є неприпустимим в дійсно правовій країні. Проблема 3 тими непередбаченими законом добровільними громадськими формуваннями правоохоронної спрямованості потребує негайного вирішення. Недопустимим є прихову- вання таких структур, як суто громадських об'єднань без належного нагляду та контролю з боку Національної поліції України. Особливо небезпечним є використання деякими державними структурами таких активістів для вирішення протизаконних питань у тих випадках, коли необхідно приховати свій зиск у їхньому вирішенні.

У наукових публікаціях виділяють дві групи громадських формувань, які беруть участь у правоохоронній діяльності: спеціально створені для протидії правопорушенням та охороні громадського порядку, також ті, для яких виконання правоохоронних функцій є додатковими до основної їхньої діяльності. До першої групи відносять громадські формування 3 охорони громадського порядку, громадські пункти охорони громадського порядку, товариські суди тощо. Основними критеріями ефективності діяльності цих суб'єктів є належний рівень забезпечення громадського порядку на території їхньої діяльності. До іншої групи суб'єктів відносять громадські, селищні, сільські, вуличні, квартальні, дільничні, домові комітети; ради ветеранів; батьківські комітети тощо. Для цих суб'єктів діяльність щодо охорони громадського порядку є неосновною. Виконання правоохоронних функцій ними є додатковою до їхньої основної діяльності. Адже основною метою їхнього створення є господарська чи соціально-культура діяльність [2]. Незважаючи на їхній вплив на підтримання правопорядку на підприємствах, установах чи певній території, ми не можемо віднести їх до повноцінних суб'єктів правоохорони. На нашу думку, до суб'єктів правохорони доцільно відносити лише ті громадські формування, основною метою яких є правоохоронна діяльність.

Діяльність громадських формувань правоохоронної спрямованості врегульована низкою нормативно правових актів, серед яких особливо слід відмітити Закони України «Про громадські об'єднання» [3], «Про участь громадян в охороні громадського порядку та державного кордону» [1], «Про органи самоорганізації населення» [4], Кодекс України про адміністративні правопорушення [5]; Постанову Кабінету Міністрів 


\section{Адміністративне право}

України «Про затвердження типового статуту громадського формування 3 охорони громадського порядку і державного кордону, описів зразків бланка посвідчення і нарукавної пов'язки члена такого формування» [6]; наказів МВС України [7].

Громадські формування 3 охорони громадського порядку і державного кордону можуть бути створені на засадах громадської самодіяльності як зведені загони громадських формувань, спеціалізовані загони (групи) сприяння Національній поліції та Державній прикордонній службі України, асоціації громадських формувань тощо. Тобто основними формами самоорганізації громадян щодо охорони громадського порядку є зведені загони громадських формувань, спеціалізовані загони (групи), асоціації громадських формувань. Інші форми участі громадян в охороні правопорядку не деталізовані. Формально немає перепон для діяльності у вигляді неприбуткових громадських організацій чим і користуються так звані «активісти». Такі організації, з одного боку декларують, що вони створені для охорони громадського порядку та громадського спокою, а з іншого - посилаються на Закон України «Про громадські об'єднання», який не передбачає вимог узгоджувати створення та діяльність таких форм самоорганізації населення з Національною поліцією та Державною прикордонною службою.

Закон України «Про участь громадян в охороні громадського порядку та державного кордону» визначає суб'єктів ініціювання створення громадських формувань 3 охорони громадського порядку. Серед них виділено: а) громадяни, які за власною ініціативою створюють громадські формування за місцем проживання, роботи чи навчання; б) органи місцевого самоврядування, окремі територіальні громади, місцеві державні адміністрації, які ухвалюють рішення про необхідність створення зазначених формувань для охорони правопорядку на відповідній території; в) органи Національної поліції України та Державної прикордонної служби; г) спільне ініціювання органами місцевого самоврядування, окремими територіальними громадами, місцевими державними адміністраціями 3 територіальними підрозділами Національної поліції в рамках адміністративних договорів, що укладаються між даними суб'єктами.

Зазначений вище закон вступив у силу ще у 2000 року за часів президентства $\curlywedge$ оніда Кучми. Очевидно, за цей час положення цього закону морально застаріли та не відповідають міжнародним стандартам. Таким чином, нині дійсна форма участі громадян в охороні громадського порядку i державного кордону має багато негативних факторів. Громадські формування з охорони громадського порядку і державного кордону перетворюються на кишенькові армії органів місцевого самоврядування чи політичних діячів або діють на власний розсуд, поза контролем органів Національної поліції і підрозділів Державної прикордонної служби України [8].

Окрім того, результати аналізу його окремих норм показали, що закон не забезпечує в повній мірі дотримання прав людини і можуть призвести до небезпечних зловживань своїми повноваженнями як органів Національної поліції України та Державної прикордонної служби України, так і членами вищевказаних громадських формувань. Адже обсяг повноважень членів громадських формувань рівноцінний обсягу повноважень посадових осіб Національної поліції України і Державної прикордонної служби України, тому фактично громадські формування з охорони громадського порядку і державного кордону виконують функції держави, не маючи при цьому необхідної кваліфікації.

Крім того, зазначений закон не визначає саме поняття «громадського формування», в інших законодавчих актах цей термін взагалі не використовуються. Законом України «Про громадський об’єднання» передбачено дві форми таких об'єднань: громадські організації та громадські спілки. Фактично відсутне нормативне закріплення порядку організації взаємодії таких формувань 3 правоохоронними органами. Це, у свою чергу, є вкрай важливим, адже Закон України «Про участь громадян в охороні громадського порядку та державного кордону» дозволяє таким громадським формуванням діяти винятково за погодженням органів 
Національної поліції та Державної прикордонною служби. I будь-яка інша діяльність матиме ознаки протизаконної.

Усі форми та методи роботи громадських формувань 3 охорони громадського порядку і державного кордону здійснюється під контролем органів Національної поліції, підрозділів Державної прикордонної служби України (ч. 1 ст. 11 Закону). До таких форм віднесено: 1) спільне $з$ поліцейськими, прикордонниками патрулювання i виставлення постів на вулицях, майданах, залізничних вокзалах, в аеропортах, морських і річкових портах, у місцях компактного проживання громадян, розташування підприємств, установ, організацій, навчальних закладів, а також у місцях можливої появи порушників кордону в межах району, що контролюється Державною прикордонною службою України, прикордонної смуги; участі в забезпеченні охорони громадського порядку під час проведення масових заходів, погоджених у випадках, передбачених законом, з виконавчими органами місцевого самоврядування; 2) проведення разом 3 прикордонниками огляду на маршрутах можливого руху порушників державного кордону, місць їх укриття, транспортних засобів, суміжної 3 державним кордоном місцевості з метою встановлення причин та умов перебування невідомих осіб; 3) участь у заходах правоохоронних органів, спрямованих на боротьбу з окремими видами правопорушень.

Однак ані органи Національної поліції, ані Державної прикордонної служби не мають нормативно-правового регулювання реалізації такої процедурної діяльності. Ще більш не визначеним $є$ роль місцевих державних адміністрацій, органів місцевого самоврядування у взаємодії 3 громадськими формуваннями 3 охорони громадського порядку та кордону. Закон вказує лише, що ці суб'єкти здійснюють координацію діяльності громадських формувань та «надають всіляку допомогу та підтримку у створенні громадських формувань 3 охорони громадського порядку і державного кордону». Інші положення цього Закону щодо обов'язків місцевих державних адміністрацій та органів місцевого самоврядування $є$ також суто абстрактними й не містять способів реалізації цих обов’ язків.

Закон №1835-III від 22.06.2000 «Про громадські формування 3 охорони громадського порядку та державного кордону» фактично повторюе всі положення Указу Президії Верховної Ради СРСР «Про основні обов'язки та права народних дружин по охороні громадського порядку» від 27.05.1974 р. [9]. Ми можемо спостерігати майже точне копіювання значної кількості положень, що стосуються прав та обов'язків добровільних народних дружин, які були закріплені у радянському законодавстві. Більшість відмінностей є незначними або взагалі неактуальними в сучасних умовах (наприклад, право використання засобів телефонного зв'язку підприємств, установ, організацій у службових цілях. Чи не єдиною важливою відмінністю даних нормативноправових актів є питання підпорядкування таких громадських формувань. Якщо за чинним законодавством ці громадські формування формально не підпорядковані органам виконавчої влади, а лише мають діяти у взаємодії з Національною поліцією та Державною прикордонною службою, то за радянським законодавством вони знаходилися у підпорядкуванні районних, міських, селищних та сільських Рад депутатів трудящих та їхніх виконавчих комітетів. При цьому самі добровільні народні дружини, як свідчить їхня назва, створювалися на окремих підприємствах, установах, організаціях на добровільних засадах. Однак слід зазначити, що радянська правова система передбачала жорстку вертикаль влади і ніщо в країні не могло діяти поза жорстким контролем з боку держави.

Діяльність усіх суб'єктів, які зазначені в Законі України «Про громадські формування $з$ охорони громадського порядку та державного кордону», передбачає їхню спільну реалізацію разом з органами та підрозділами як Національної поліції, так і державної прикордонної служби. За своєю сутністю, діяльність зазначених громадських формувань не може мати ізольований та самостійний характер, а має здійснюватися винятково у співпраці 3 державними правоохоронними органами. Уся система побудована 


\section{Адміністративне право}

на радянській системі свідомої допомоги громадян державним структурам. Однак така допомога $є$ можливою лише за наявності реальної довіри з боку громадськості. Не можна сподіватися на допомогу за мінімальної довіри населення до поліції. Майже всі соціологічні дослідження, які проводили в останні роки існування міліції, свідчили про вкрай низький рівень довіри населення до даного правоохоронного органу. При цьому спостерігалося стійке падіння рівня довіри з 5 відсотків в 2010 до 0,8 відсотки в 2014 [10]. Ситуація, за думкою реформаторів, мала змінитися із реорганізацією міліції в «нову поліцію». Запровадження оновленої патрульної служби надало певний аванс довіри з боку населення. Однак уже протягом одного року позитивні очікування населення змінилися на протилежні. Яскрава картинка, яка подавалася в засобах масової інформації, ніяк не корелювалася з реальним станом громадської безпеки в країні. Корупційні та інші скандали майже повністю знищили залишки авторитету державних правоохоронних органів.

У зв'язку з викладеним, говорити про дієву систему взаємодії населення та державних правоохоронних органів на цьому етапі говорити не можна. Необхідним є відновлення довіри населення до поліції. Основною умовою такого відновлення $є$ чітке дотримання норм закону з боку працівників поліції, неухильне дотримання прав і свобод громадян, активна профорієнтаційна робота. Необхідно, щоб поліція дійсно виконувала сервісну функцію щодо населення. Використання поліції виключно як карального органу лише поглиблюватиме кризу неприйняття ії діяльності з боку населення.

Звісно, не можна залишати поза увагою всі ті негативні соціально-економічні зміни, яких зазнала наша країна протягом останніх десятиліть. Злам економічної моделі існування країни, «дикий капіталізм», первинне накопичення капіталу, свавілля чиновників не могли не позначитися на соціальному устрої. За радянських часів модель залучення громадськості до охорони громадського порядку базувалася на виробничому принципі - добровільні народні дружини створювалися здебільшого на під- приємствах чи в окремих державних організаціях. Активно ця модель реалізовулася й в навчальних закладах, в домоуправліннях та квартальних комітетах. Існувала чітка система стимулювання участі громадян в охороні громадського порядку. Звісно, за адміністративно-командної системи не було особливих проблем із організацією сприяння участі громадян в охороні громадського порядку з боку керівництва підприємств, установ, організацій. Це було пов'язано 3 тим, що, по суті, всі підприємства, установи й організації були державними. На керівництво зазначених підприємств був покладений обов'язок матеріального забезпечення добровільних народних дружин. Зокрема, для штабів ДНД виділялися окремі приміщення, необхідні меблі, інше матеріальне забезпечення. Добровільним народним дружинам для виконання їхніх завдань виділявся транспорт та засоби зв'язку. Окрім звичайних моральних заохочень за активну участь у боротьбі з правопорушеннями, народним дружинникам надавалися додаткові відпустки строком до трьох діб, переважного права на одержання жилої площі надання пільгової путівки до санаторію або будинку відпочинку тощо. Зрозуміло, що такий спосіб заохочення майже неможливо реалізувати в умовах жорсткої ринкової економіки. Власники підприємств не мають бажання витрачати додаткові кошти на те, що безпосередньо не приносить прибутку, й, відповідно, не зацікавлені у підтриманні роботи громадських формувань 3 охорони громадського порядку.

Іншою складовою, яка забезпечувала дієвість системи добровільних народних дружин, була єдина партійна система, яка мала свої представництва й осередки майже у всіх підприємствах і організаціях, навчальних закладах тощо. Ця партійна система здійснювала певний тиск як на керівництво підприємств, так і на працівників. Ідеалізована «добровільність» добровільних народних дружин здебільшого мала примусовий характер. Існувала система розрахунків на участь певної кількості осіб у ДНД на кожному підприємстві.

Зазначені вище радянські способи заохочення залучення громадян до охорони 
громадського порядку неможливо застосувати в нинішніх умовах. У зв’язку з цим необхідно відшукувати нові способи такого заохочення. Насамперед, необхідно вирішити дві глобальні проблеми: недосконалість правового регулювання діяльності громадських формувань 3 охорони громадського порядку, а також низький рівень довіри до поліції. Вирішення проблеми нормативного регулювання залежить лише від політичної волі й не вимагає значного часу. У той же час проблема довіри населення до державної правоохоронної системи є вкрай складною. Її неможливо вирішити кількома законами - це довготривалий і складний процес. Якщо раніше наголос робився на робітників підприємств, нині варто звернути увагу, насамперед, на навчальні заклади. Студентство є найбільш активною категорією населення. Правильно поставлена агітаційна робота серед студентства у поєднанні 3 правовим вихованням може дати швидший результат. 3 цього приводу слушною 6 пропозиція С. С. Юрка про залучення студентів та курсантів навчальних закладів, що займаються підготовкою кадрів працівників поліції як громадських помічників поліції та членів відповідних студентських дружин при такого роду закладах [11, с. 185]. Такий підхід, фактично, зможе стати елементом профорієнтаційної роботи національної поліції щодо підбору кандидатів на службу в органи Національної поліції. Основними суб'єктами такої діяльності мають бути вищі навчальні заклади із специфічними умовами навчання, які знаходяться у підпорядкуванні МВС України. Такі навчальні заклади мають значний досвід у підготовці працівників правоохоронної сфери. Правова підготовка студентів щодо порядку здійснення правоохоронних заходів, навички складання процесуальних документів, практика спільного патрулювання з працівниками поліції збільшуватиме кількість осіб, які матимуть змогу реально виконувати правоохоронні функції й стати в подальшому правоохоронцями.

\section{Висновки}

Якщо детально проаналізувати досвід залучення громадян до охорони громадського порядку в нашій країні, інших країнах, не можна стверджувати на недоцільності такої практики. Це не залишки «совка», якого слід позбутися. Не можна відкидати досвід, який був набутий за часи перебування України в складі СРСР. Визнавати якісь факти та практику лише на підставі того, що це використовувалось радянською владою, є ознакою обмеженості у сприйнятті дійсності. У багатьох країнах світу існує практика залучення громадян до охорони громадського порядку та спільної діяльності з правоохоронними органами. Зокрема, Японія останні десять років впроваджує саме радянський досвід залучення громадян до такої діяльності. Окрім аналогів добровільних народних дружин, у Японії активно розвивається діяльність аналогів квартальних комітетів, які існували в нашій країні.

Рівень залучення громадян до співпраці 3 правоохоронними органами щодо забезпечення правопорядку та протидії злочинності є еталоном розвитку в країні громадянського суспільства. Активна громадянська позиція, яка підкріплюється довірою до державних інституцій, може якісно змінити на краще співжиття всіх членів суспільства.

\section{Література}

1. Про участь громадян в охороні громадського порядку i державного кордону: Закон України від 22.06.2000 № 1835III. URL: http://zakon3.rada.gov.ua/laws/ show/1835-14

2. Профілактика злочинів: підручник / [О. М. Джужа, В. В. Василевич, О. Ф. Гіда та ін.]; а заг.ред. докт. юрид. наук, проф.О.М. Джужи. К.: Атіка, 2011. 720 с.

3. Про громадські об'єднання: Закон України від 22.03.2012 // Відомості Верховної Ради України. 2013. № 1. Ст. 1. URL: https://zakon.rada.gov.ua/laws/show/4572-17

4. Про органи самоорганізації населення: Закон України від 11.07.2001№ 2625-III. URL: http://zakon.rada.gov.ua/ laws/show/2625-14

5. Кодекс України про адміністративні правопорушення: Кодекс України від 07.12.1984 № 8073-X. URL:http://zakon.rada. gov.ua/laws/show/80731-10

6. Про затвердження типового статуту громадського формування 3 охорони гро- 


\section{Адміністративне право}

у статті проаналізовано сучасний стан правового регулювання порядку залучення громадян до охорони громадського порядку в Украіні. Відзначається декларативний та безсистемний підхід щодо залучення громадян до охорони правопорядку. Розглянуто спірні положення Закону Украӥни «Про участь громадян в охороні громадсъкого порядку та державного кордону». Звернуто увагу на відсутність правового визначення самого поняття «громадсъкого формування», яке не використовується в інших законодавчих актах. Фактично відсутне нормативне закріплення порядку організациї взаємодії таких бормувань з правоохоронними органами. Діяльність зазначених громадських бормувань дозволяється винятково за погодженням органів Національної поліиї та Державної прикордонною служби, будь-яка інша діяльність матиме ознаки протизаконної. Наголошено, що за своєю сутністю діяльність громадських формувань з охорони громадсъкого порядку не може мати ізольований та самостійний характер, а має здійснюватися виключно у співпрачі з державними правоохоронними органами. Визначено основні способи стимулювання участі громадян в охороні громадсъкого порядку та визначено перспективи такої діяльності в нашій краӥні.

Ключові слова: охорона громадсъкого порядку, правоохоронні органи, борми взаємодї, громадські бормування.

мадського порядку і державного кордону, описів зразків бланка посвідчення і нарукавної пов'язки члена такого формування: Постанова Кабінету міністрів України від 20.12.2000 // Офіційний вісник України. 2000. № 52. ст. 2259. URL: https://zakon.rada. gov.ua/laws/show/1872-2000-\%D0\%BF

7. Про затвердження Інструкції про порядок придбання, видачі та зберігання спеціальних засобів членів громадських формувань з охорони громадського порядку : Наказ МВС України від 27.04.2007 // Офіційний вісник України. 2009. № 55. ст. 1947. URL: https://zakon.rada.gov.ua/laws/show/ z0644-09

\section{SUMMARY}

The article analyses present state of legal regulation of citizens' involvement in community policing in Ukraine. It ascertains declarative character and haphazard approach to citizens' involvement in community policing. The article reviews controversial provisions of the Statute of Ukraine "On Citizens' Participation in Community Policing and Protection of the State Border". It emphasizes the lack of definition of community groups that is not used in other legislative acts. It also outlines the lack of legislative regulation of collaboration of such groups with law enforcement agencies. The activity of such community groups is legitimate only upon reconciliation with organs of the National Police and the State Border Service; any other activity would be considered illegal. The article emphasizes that according to its nature activity of community groups must not be incoherent and independent. It must be conducted exceptionally on the collaborative bases with state law enforcement agencies. The article outlines major ways of encouraging citizens' participation in community policing and uncovers the perspectives of such activity in our state.

Key words: community policing, law enforcement agencies, forms of collaboration, community groups.

8. Пояснювальна записка до проекту Закону України «Про внесення змін до деяких законодавчих актів України щодо удосконалення окремих положень з питань охорони громадського порядку і державного кордону». URL: http://w1.cl.rada.gov.ua/ pls/zweb2/webproc34?id = \&pf3511=63749\& pf35401 $=451046$

9. Об основных обязанностях и правах добровольных народных дружин по охране общественного порядка : Указ Президиума Верховного Совета СССР от 20 мая 1974 года URL: http://pravo.gov.ru

10. Питання реформування органів внутрішніх справ України: Розпорядження КМУ від 22.10.2010 // Офіційний вісник України. 2014. № 96 Ст. 2767.

11. Юрко С. С. Недержавна охоронна i правоохоронна діяльність в Україні: дис. ... канд. юрид. наук. 12.00.10. Одеса, 2017. 252 с. 